\title{
Geneotype and phenotype in 20 patients with glycogen storage disease type la
}

\author{
Cuili Liang, Li Liu*, Huiying Sheng, Minyan Jiang, Xi Yin \\ From 7th APPES Biennial Scientific Meeting \\ Nusa Dua, Bali. 14-17 November 2012
}

\section{Background}

Glycogen Storage Disease Type Ia (GSD Ia) is a group of autosomal recessive inborn errors of metabolism that is caused by deficiency in glucose-6-phosphatase,and it is the major subtype of Liver Glycogen Storage Disease (LGSD) cases. Patients afflicted with GSD Ia cannot maintain glucose homeostasis and manifest hypoglycemia, hepatomegaly, lactic academia. However, we cannot separate GSD Ia form LGSD through clinical manifestations and routine laboratory tests, except for analysis of G6PC gene mutation and assay of glucose-6-phosphatase enzyme activity, which is an invasive method. Therefore, the analysis of G6PC gene mutation is an important method for diagnosing GSD Ia.

\section{Objective}

To investigate the G6PC gene mutations in patients with Glycogen Storage Disease type Ia (GSD Ia),and analyze the relationship of its genotype and phenotype.

\section{Methods}

We diagnose 48 patients with LGSD by clinical manifestations, laboratory tests and glucagon test. The entire coding region of the G6PC gene from peripheral blood was screened by PCR combined with direct DNA sequencing. The G6PC genes of 50 unrelated healthy children were investigated as comparisons to rule out gene polymorphism. We used software named DNAMAN to analyze their conservatism through many species homology comparison.

\section{Results}

Among 48 patients, there were $41.67 \%(20 / 48)$ of them were found to have G6PC gene mutations. Totally eight types of G6PC gene mutations were detected, which

Department of Pediatric Endocrinology and Metabolism, Guangzhou Women and Children' Medical Center. Guangzhou, Guangdong, China were 727G>T, R83H, H119L, L173P, I341N, V88Xfs254, $\mathrm{C} 109 \mathrm{~T}$ and W87Xfs270, and $727 \mathrm{G}>\mathrm{T}$ and $\mathrm{R} 83 \mathrm{H}$ were more frequent, with frequencies of $37.50 \%(15 / 40)$ and $22.50 \%(9 / 40)$, respectively. C109T and W87Xfs270 were never reported before. Our clinical and routine laboratory data showed that the patients manifested the same phenotype even with different genotype.

\section{Conclusions}

Our study revealed $727 \mathrm{G}>\mathrm{T}$ and $\mathrm{R} 83 \mathrm{H}$ mutations were prevalence in Chinese patients with GSD Ia. C109T and W87Xfs270 might be novel pathogenic mutations. There was no clear relationship between genotype and phenotype.

Published: 3 October 2013

doi:10.1186/1687-9856-2013-S1-P175

Cite this article as: Liang et al:: Geneotype and phenotype in 20 patients with glycogen storage disease type la. International Journal of Pediatric Endocrinology 2013 2013(Suppl 1):P175.

Submit your next manuscript to BioMed Central and take full advantage of:

- Convenient online submission

- Thorough peer review

- No space constraints or color figure charges

- Immediate publication on acceptance

- Inclusion in PubMed, CAS, Scopus and Google Scholar

- Research which is freely available for redistribution

\section{Biomed Central}

(c) 2013 Liang et al; licensee BioMed Central Ltd. This is an Open Access article distributed under the terms of the Creative Commons Attribution License (http://creativecommons.org/licenses/by/2.0), which permits unrestricted use, distribution, and reproduction in any medium, provided the original work is properly cited. 